\title{
NEW CHALLENGES FOR URBAN ETHNIC COMMUNITY RESEARCH: DIGITALIZATION AND COLLABORATION
}

ZSOLT SZIJÁRTÓ'

\begin{abstract}
The focus of this study is one of the frequently emerging topics of social science research: the investigation of metropolitan ethnic communities. The sociopolitical-media-cultural changes of recent decades (globalization, mediatization, digitization) have completely transformed the phenomenon of metropolitan migration; new questions and problems have been raised for social scientists, politicians, and various social groups, which have encouraged them to apply new approaches. The study showcases the new perspectives and methodological possibilities of research into metropolitan ethnic communities, one of which is digitization and the other is collaborativity. The novelty of posing this question is methodological. The study describes how knowledge generated by ethnic communities can be gathered with their help, then organized and reused in urban planning processes. It involves at the same time urban researchers, social scientists studying ethnic groups, and urban planners. The empirical background of this study is anthropological fieldwork undertaken in the Hungarian diaspora in Berlin.
\end{abstract}

KEYWORDS: ethnic communities, digitalization, collaboration, urban planning, community archiving, digital anthropology

\section{INTRODUCTION AND THEORETICAL BACKGROUND}

Since the 1920s, metropolitan ethnic communities have constantly been a focus of social science (sociology and cultural anthropology) with varying

1 Zsolt Szijártó is a habilitated doctor, professor, and Head of Institute of Social Sciences, and Head of Department of Communication and Media Studies at the University of Pécs, e-mail: szijarto. zsolt@commonline.hu 
intensity, and huge amounts of data and knowledge have accumulated through their research. At the same time, the social, political, media and cultural changes of the last decades (keywords: globalization, medialization, digitalization) have completely transformed the phenomenon of metropolitan migration, and new questions and problems have been raised for social scientists, politicians, and social groups which have encouraged new approaches on their part (Bojadžijev - Römhild 2014).

New types of metropolitan migration processes have emerged, which - as the new literature finds (Glick et al. 1992; Glick et al. 2006; Çağlar 2002; Vertovec 2007) ${ }^{2}$ - cannot be described in terms of traditional binary opposites (emigrant country - host country, immigrant - emigrant, etc.) and traditional conceptualization, and also cannot be interpreted as a merely linear movement that leads from one nation state to another. Instead, the everyday practices of different migration communities can be captured as a form of complex network building with its own dynamic that takes place in a transnational-global space, both online and offline (Diminescu 2008). And, in this process, the various metropolitan localities play a prominent role. ${ }^{3}$

Recent research has attempted to reflect on these developments. For example, the former now goes beyond the concept of self-contained ethnic groups, which has been a long-established premise of community research, and outlines at least two important contexts around these groups. One is the urban medium in which they arrive, move, live, work, and rest which serves as a framework for their daily lives and which is constantly transforming as a result of current trends in urban development (changes in the real estate markets, current urban economy, demographic migration processes) (sublurban 2014). The other, increasingly important context that is essentially determining the everyday life of ethnic groups is the ever-changing repertoire of communication technologies that allow ethnic groups living in big cities to interact with each other, with

2 Within the context of this article, it is not possible to present a detailed description of the literature on metropolitan migration; only the aspects relevant for the subsequent line of thought are highlighted.

3 To distinguish the types of urban migration, Ludger Pries uses four ideal types. The "classic model" can be described using the concepts of emigration and immigration, and records movement in which migration communities leave their place of origin and settle permanently in the new country of their choice. A different pattern is indicated by "periodic or circular migration," where participants do not plan to settle permanently, but move between countries for economic reasons. "Diaspora migration" focuses on the organization and functioning of communities in host societies, while the concept of "transnational migration" focuses on the multidirectional movement of participants. Of course, these categories do not exist in their pure form, and the boundaries between them are liquid, but at the same time they help distinguish the types of migration. In the communities I studied, a mixture of these types of migration could be seen, in many cases following generational patterns (Pries 2010). 
locals, and with "those back at home" in various ways (Hepp - Düvel 2010).

The relationships that exist between the components of this three-element system - city/migration/medium - are studied in themselves by independent and rather diverse research trends. ${ }^{4}$ Thus, the relationship between migration and the media has long been studied by sociologists and media researchers, and the focus of their research is the specific media consumption (sometimes media production) of ethnic groups, the role of media in social integration or segregation, the media visibility/invisibility of ethnic groups, and the list goes on (Hepp - Düvel 2010). The relationship between the city and media systems also emerges in several contexts: literary and film historians and media researchers are investigating the historically changing ways of how cities are represented in different media, and analyzing cities' successful and sometimes less successful attempts to create their own visual image and brand (Szijártó 2010).

\section{Posing the question}

The current paper deals with the third element of this context system: it discusses the relationship between city and migration (and, in a wider context, the relationship between space and mobility, and place and community). Editorial (2014) considers this complicated, difficult to comprehend relationship only from the specific perspective of heritage creation and museumization. Research in this field, mainly related to ethnology and museum studies, poses the fundamental question of how migration becomes part of a city's history (or its stories), and how migration can shape the self-representation and identity of the city. What different, time-varying strategies can be observed in urban policy and on the part of urban cultural institutions, such as museums and educational institutions, when processing the ethnic history of the city? How do the members of the ethnic groups in question relate to these views and actual practices? What recent changes and transformations have occurred in

\footnotetext{
4 As is apparent from the theoretical framework, several disciplines pay special attention to the problems of metropolitan migration. The economic approach emphasizes the decisive influence of income differences between the home and the target country (Faist 2016). Another trend, focusing on the experiences of migrants, tries to reconstruct the dynamics of migration paths (De Haas 2010). One variation of this is relational capital, which highlights the fundamental role of networks in the migration process. Research on transnational spaces created by migration has become a separate research trend (Glick Schiller - Salazar 2013). The approach of this study lies at the intersection of digital anthropology and communication and media science, and examines how new communication tools and platforms change the set of conditions for migration, and how the same infrastructure can be used in the research of the phenomenon (Host - Miller 2012, Miller et al. 2016).
} 
the strategies for processing and exhibiting the city's ethnic past? What external and internal factors, cultural, political, and media technological determinations have formed and influenced the activities of the institutional system?

How ethnic groups relate to the history of the city is also an important and current topic, because in the last decade the growing debate ${ }^{5}$ around migration has also characterized the field of museums and exhibitions (Bojadžijev Römhild 2014). While in the past the existence, number, and the impact of different ethnic groups on urban development were not really decisive factors in the self-representation of German cities, in the last decade there have been several exhibitions that have shown the evolution of urban development through stories of migration. ${ }^{6}$ Berlin has a special place in this respect as Kreuzberg, an area mainly inhabited by Turks in the past, is an important one of the city's tourist attractions, and just this makes the presence of ethnic groups in the city unavoidable. In addition, the city tends to describe itself as a "creative metropolis" (Krätke 2001), and different ethnic communities serve as an essential background, or some sort of folkloric stage, to this lifestyle.

There are two positions concerning how to represent different ethnic groups in a city's history (sub/urban 2014). The more traditional approach focuses on the concept and process of "integration" (Hepp - Düvel, 2010). According to this narrative, migration is a process defined in time, with apparently clear starting and end points, in which the state is the most important actor as its needs and regulations define and identify the room for maneuver of each ethnic group. In contrast to this, there are different approaches focusing on diversity. On the one hand, these assist in a critical review of the concept of integration, and offer different concepts instead (such as "cultural diversity," "social mixing," "migration as a resource"), and on the other hand, they include different, thus far neglected dimensions of the urban existence of ethnic groups in their research. Emphasis is placed on self-organized (non-governmental) ethnic and migration projects, transnational networks, and various discursive contexts. This research seeks to make ethnic groups more aware of their own urban history, and encourages them to use it as a resource in various urban policy and development debates.

The approach of this study is sympathetic to views sensitive to the diversity and self-organizing processes of ethnic groups, and to views more sensitive

5 In particular, the fiftieth anniversary of the agreement on guest workers signed by the Turkish and German States in 1961 encouraged a number of cultural and urban institutions in Germany to create a new visibility policy.

6 For example, the title of an exhibition organized for 775th anniversary of Berlin in 2012 was revealing in itself: Stadt der Viefalt (City of Diversity). The large open-air exhibition on Schlossplatz was based on a walkable city map, where texts placed at different locations displayed migration stories that were typical of urban development as a whole. 
to discursive contexts, but also uses multiple elements of integration-based approaches. Thus, for example, it takes into account the legal and administrative frameworks created by the different nation-state instances and governmental organizations (Ministry of Foreign Affairs, embassies, Ministries of Culture) that have fundamentally influenced the playing fields of the ethnic group (and its self-organization). It also considers the historicization of the concept of "integration" important, as the imperative hidden in this concept and the relationship with majority society have meant different things for different generations.

\section{The relevance of the question}

This issue is also worthy of emphasis because of the recent technological and cultural changes that have affected projects aimed at the collection and preservation of past memories of certain ethnic groups. Of these, I would like to briefly mention two; however, their detailed presentation is unfortunately not possible within the scope of this paper. Naturally, these changes are not limited to the research of urban ethnic groups, but are of wider scope, and are also valid in relation to other communities and social groups; however, they also play a crucial role in this area.

One is digitalization, which has completely redefined the criteria for the creation, construction and use of memory repositories and archives, and has established new technologies and methods of gathering and displaying (urban) cultural heritage. (This is discussed in more detail below.)

The other change has more of a cultural nature. In recent years, due to a number of factors such as the growing influence of city marketing and city branding, there has been an increased sensitivity to alternative systems of knowledge and symbols created by various groups in urban society. By incorporating these into the self-representation and "identity" of the city, they are capable of contributing to its uniqueness and unmistakable character. At the same time - and this relates more to the transformation of the preferences of cultural and scientific policy - the default attitude of the cognitive process itself has changed. There has been an increase in the criticism of the system of relationships that has defined scientific understanding for centuries, which is built on the hierarchical situation between the researcher and the researched, on power asymmetries, and on pre-established subordination and superiority. A growing number of alternative concepts have emerged that experiment with rethinking the cognitive process and have attempted to break down this hierarchical structure. 
These critical views are mostly crystallized around the concept of "participation." It has been considered important that those involved in the research (i.e. the representatives of these groups) should also be engaged in the stages of the cognition process (Terkessidis 2015). It has also been considered crucial for members of these communities to control the use of the knowledge generated about them. All these efforts have not remained at the level of individual experimental projects, but have culminated in a turning point for participation, which is why we can increasingly encounter various forms of participation in scientific research, presentations, and the use of scientific knowledge (Császár 2013). (These two areas are linked in many ways, as opportunities for participation, among other things, have been created by the affordances of digital infrastructure, and the processes of meaning production and consumption in the digital space - as several agree, such as the American media researcher Henry Jenkins and his oeuvre - has led to the emergence of a "participatory culture" [(Jenkins 2006]).

The current paper examines how these changed principles and new cultural and technological criteria of scientific understanding can be implemented when collecting, archiving, and utilizing the heritage of a particular ethnic group. It suggests a particular medium for research, archiving, and presentation activity: the creation of map-based digital platforms that can serve multiple functions. On the one hand, these are capable of presenting - both historically and in terms of synchronicities - the most important areas of everyday life of a particular (ethnic) group, as well as the most basic spatial reference points of its recent history. On the other hand, they offer an opportunity for the collection, processing, and "archiving" of previously created cultural-artistic products, as well as the knowledge and understanding collectively generated by these groups. It is an important expectation of digital platforms that they should work as a collaborative interface where members of the groups can display themselves, interact with others, and comment on and add to the material collected in the archive. It is a platform that is both an archive and a community space; both the object and the result of research.

\section{THE AREA OF EXAMINATION}

The focus of the research is the various groups of Hungarians living in Berlin, who are mainly organized on a generational basis. Between October 15, 2016 and December 15, 2016, I spent two months in Berlin. My research was related to a traditional area of Hungarian studies, the contemporary social science (cultural 
anthropological) study of Hungarian communities living abroad (in this case, the different Hungarian groups in Berlin). At the same time, it tried to approach this classical topic by raising new questions both thematically (mainly using the most important theoretical basics of digital anthropology) and methodologically. Thus, special attention was given to the technologies and methodological tools supporting new methods of scientific cognition: among others, community-led cultural mapping initiatives.?

According to more than 30 interviews conducted as part of field research, every 10-12 years, in the context of socio-political changes, ${ }^{8}$ the orientation of different groups in everyday life transforms, and their relation to urban space, society, their media environment, and their media use changes as well. This is also the case for individual Hungarian groups in Berlin, who have intensively created different cultural-artistic products in recent times, developed various forms of knowledge and skills, and formulated action strategies with regard to the representatives and the institutional system of urban politics. The sites created by these groups in the urban space (salons, shops, exhibitions, cafés, restaurants, concert venues, etc.) have served different functions: they have facilitated cultural practices and created opportunities to build relationships and create cultural ideas about their own situation.

At the same time, one of the major characteristics of these groups - and the knowledge and skill forms they create - is invisibility; dissolution in the majority urban space. Indeed, an important task of the research is to collect and visualize this cultural heritage, this alternative knowledge system, which is at the same time part of Berlin's city history and Hungarian cultural and social history. This archiving work is all the more important because the forms of knowledge and skills generated by the ethnic groups are volatile in the absence of proper institutionalization, and they soon fade and disappear without a trace. In the meantime, they convey important knowledge about certain groups of Hungarian society, and what it means to participate in the society, culture and everyday life of a Western European city, and to contribute to the (meaning) production processes involved there.

This project combines several seemingly remote cultural-social areas, such as archiving the past and planning the future, private memory and public events, abstract urban-spatial structures, and personal-sensual meanings. Accordingly,

7 The current text is primarily aimed at presenting the methodology and the principles, while the presentation of the results will be the subject of another study.

8 Some of the major policy frameworks that have shaped urban mobility: 1989/1990 - Central and Eastern European political system change; 2004 - Hungary's entry into the European Union; 2011 - opening of the German labor market. 
a number of disciplinary areas are involved in the research, interpretation, and presentation process: cultural mapping, community archeology, visual archive creation and crowdsourced planning all offer important concepts and good practices.

\section{THE METHOD: ON CULTURAL MAPPING}

"Cultural mapping" is a young and emerging interdisciplinary area involving vastly different types of activities. ${ }^{9}$ In addition to statistics, it is part of the traditional toolkit of urban administration and management, and is also an important tool for "indigenous groups" who are acting against central management and are demanding rights related to a given area. ${ }^{10}$ It can be associated with various artistic activities, and is also of great importance for academic knowledge production, but it can be considered a particular social practice associated with a group as well. The resulting maps provide an abstract reading of the geographical space for the viewer, while behind the data represented on the maps one can find the material and symbolic processes and the chains of action of the "lived social space." It can strive for a "space-reading" from a hierarchical perspective (or, as the geographer, Denis Cosgrove put it, "create the diverse needs of truth and authority" [Cosgrove 2008]), but can also be seen as a practical tool that can help with participation-based planning and development, and which can appeal to various groups of the public. According to a very pragmatic

9 Traditionally, the scientific significance of cartography was to record the characteristics of geographical space as accurately and realistically as possible during the mapping process. Later, as a result of changes within geography, more and more criticism was raised against the unrevised principles of maps and map making (Manoff, 2014). The concept that maps are texts, discourses, and special media in which social practices, cultural ideas and hierarchies are formulated has become increasingly important (Kitchin et al. 2009). This study also considers cultural mapping as a form of social action that simultaneously informs about the important features of space, records the legacy of the past, and enables future planning (Stewart 2007).

10 Two distinct definitions support the cross-sectoral role of cultural mapping, which also offers indigenous groups opportunities for identification and asserting their interests: "Cultural mapping, with its incorporation of both qualitative and quantitative mapping of cultures (...) was seen as a catalyst and vehicle for bringing together the academic, community, industry, and government sectors, as well as a fruitful context for the convergence of skills, knowledge, and interests" (Duxbury et al. 2015, 1-45, 7), and "cultural mapping was viewed as an activity pursued by communities and their constituent interest groups to identify and record an area's indigenous cultural practices and resources, as well as other intangibles such as their sense of place and social value" (Ibid). 
definition, cultural mapping is a "process of collecting, recording, analyzing and synthesizing information in order to describe the cultural resources, networks, links and patterns of usage of a given community or group" (Stewart 2007).

In recent years, not independently of the "participatory revolution" in politics and governance, the dialogic potential of this activity - i.e. its communicational dimension - has been at the forefront of interest. Cultural mapping is capable of mobilizing very diverse social groups and is able to create communicational bridges between the various actors of urban society (local government, local communities, NGOs). In many cases, the practice of mapping itself is now more important than the result; the map thereby created. The newer literature considers these practices as an ethnographic tool that fosters understanding of the individual perception of a particular area or a local community, and one that can provide insight "into the ways in which personal narratives and trajectories and the inflections of class, habitus, age, and gender, are constitutive of specific and often contradictory geographies of place, culture, and identity" (Roberts Cohen, 2015).

Urban ethnic groups have been in the field of interest of the collection, statistics, and mapping activities of urban authorities in two ways. On the one hand, since the 1990s, due to the introduction of asset-based community development and planning systems, more and more attention has been paid to understanding the processes in the cultural sphere, in addition to infrastructure and social areas. Due to the professionalization of planning, strategic development and urban planning started to involve growing areas of culture, and thus the demand for local cultural goods to be included on this map emerged; for example, those related to an association, civil initiative, or ethnic group. The visibility problem of the various groups was not only a chapter in the struggle for recognition and acceptance, but there were also practical goals behind it. It was important for these groups that their ideas would be counted on at a later stage when the concrete steps of planning started.

The other process is related to the current trends in urban development: the formation of the "creative city" concept (Florida 2005), among others. Also in the 1990s, a growing number of city administrations recognized that, due to global competition, it was increasingly important to enhance the visibility of the city and highlight different individual locations and identity markers, mainly to attract tourists, investors, and a well-trained work force (Taylor et al. 1996). In support of the principles set out in the concept of the "creative city," in many cases researchers (and several agencies) used a variety of maps, aiming in each case to emphasize and communicate the uniqueness and individuality of the place. In this framing and identification 
process, in addition to recording the material features and infrastructural equipment of the place, local cultures of the city (subcultures, special occupational groups, ethnic communities, etc.) played an important role. The non-material, non-tangible assets created during the daily lives of these groups make a significant contribution to creating the unique characteristics of the city, so the markers of creative cities tend to refer to their practices (Session 2010).

\section{Digitalization and smart city approaches}

The process of cultural mapping has been fundamentally transformed by the spread of digital techniques. Network technologies have changed the framework for the organization and management of urban life, and the conditions for planning and controlling processes in different urban spaces (public spaces, roads, buildings) (Replika 2015; Fejérdi - Z. Karvalics 2015). Network technologies almost automatically transport data (relating to transport, energy consumption, population size and composition, etc.) thereby allowing the inventorying of activities happening in the city, as well as the storage and potential sharing of information. Increasingly, this type of information can be classified as so-called "open data" which "anyone can freely use, re-use and redistribute, subject only at most, to the requirement of referencing the source or applying licensing conditions similar to that of the original when distributing data" (Open-DataHandbook 2012, 5). These open data are stored in open archives, usually created by city authorities.

The sudden publicity surrounding the information relating to the operation of the city is not a coincidence (Salamin 2015). It expresses the hope of local governments that the open data generated by network technologies will be directly usable in the operation of the city. ",Through new sourcesof information cities hope to create insight, innovation, opportunity and real jobs that will increase prosperity and quality of life" (Harrison - Donnelly $2011,6)$. For example, through these technologies a greater part of the urban population will be addressed and involved in the decision-shaping process, or through public information bundles that make dynamic processes that create urban life frameworks more understandable. The sharp increase in the number of Open Government Data Initiatives demonstrates that local governments are assigning a strategic role to open data when defining future trends in urban development. The emergence of the "smart city" concept and its spread in the various forums of public discourse suggest that the 
wider public opinion is also interested in the connection between network technologies and urban management and planning. ${ }^{11}$

Traditionally, two tendencies are usually distinguished in connection with the interpretation of the term "smart city." The so-called functional approaches mostly deal with data quasi-automatically generated about urban networks (traffic, electricity, water, and energy consumption) (Harrison - Donnelly 2011). These information bundles are mainly considered important because they can effectively be used to model the movement of people, objects, and information in urban space. The functional approaches, mostly represented by real estate developers, design engineers, and architects, are characterized by a systemic perception of the city, and data about the urban infrastructure can only be used in this systematic way (after careful monitoring and analysis) to make the operation of the city smarter and more effective. In summary, it can be stated that behind this approach is an "optimized, top-down interpretation of the production and distribution of each performance" (Flade 2015, 85), ${ }^{12}$ which provides a holistic reading of the processes taking place in the urban space and the methods (and means) of how urban life is organized, focusing on the problem of city operation (Replika 2015; Ders 2016).

In addition, there is another trend within the concept of the "smart city" which likewise works with open data, and its purpose is not significantly different from the functionalist approaches. At the same time, research included in this group focuses primarily on the individual niches that exist beyond the world of "big data," such as car sharing, urban gardening, and other similar participatory practices (Insole - Piccini 2013). Their purpose is none other than to uncover intangible assets - the cultural and intellectual capital - in the background of these practices (Neirotti et al. 2014). These approaches are more microscopic in nature and focus on the actors as they "magnify" the holistic city image outlined by the functionalist approaches, because this is the only way to answer the question of "why" regarding processes in urban space.

In this case, researchers also strive for a deeper understanding of urban processes, the widening of urban publicity and decision-making processes, and

11 However, the area is not free of controversy. It is not possible to address this here, but a few points of interest may be mentioned: how does the city, connecting many areas of everyday life, mean at the same time the extent of the "city of control" with its invisible techniques of supervision?; and how do new inequalities stemming from differing access to the digital world build on traditional social inequalities?

12 Critics of the approach also emphasize this: since the aim of the trend is to create a new kind of management potential for sustainable urban development, it concentrates too much on the level of city management and does not really address the issue of the involvement of the population (Flade 2015). 
aim to create conditions for greater public participation (Insole - Piccini 2013). At the same time, a different kind of city concept lies behind their activity. According to this, the complex system of the city cannot be described merely by its functions: urban life is more than just a sum of its parts, and includes countless everyday practices and individual and collective decisions (Neirotti et al. 2014) The nature of the "data" found here is different from the raw, unprocessed rows of numbers and characters generated quasi-automatically on networks. The literature calls these factors that play a key role in the creation of a city's cultural heritage "intangible urban data" (Nilsson - Wiman 2015).

\section{Community digital archives}

Among the approaches for studying microprocesses and using the open data of the city, the research of community cultural heritage and community archives plays an important role. It is well known that archives play a crucial role in reinforcing the time categories that serve as a basic organizing principle of society: the past, the present, and the future. A number of analyses have proven the hypothesis (Derrida - Ernst 2008) that an archive is not just a neutral container that preserves the events of the past, but also has a power position; it defines the conditions for access to the past by selecting the events. Archiving is important not only for the recording of the past, but also because this process can lead to the expansion of the knowledge of the city, thus new, so far invisible systems of knowledge can enter the city's cultural heritage, which in turn can be used in future planning processes. Therefore, the democratization of access (through participation and collaboration processes) and a wider base of heritage creation have increasingly been required in archive building in recent times. Some researchers are expecting digital technologies to create the democratic system of conditions for the establishment of archives (Roberts - Cohen 2015), so that various, formerly marginalized groups can be involved in previously closed, hierarchically structured processes of cultural heritage creation and archiving.

This framework can incorporate research into urban cultural heritage that focuses on the various archiving practices of ethnic groups (diasporas) and the data they create. These communities are not really visible in the majority urban spaces, and are generationally fragmented, with significant differences in the value system and lifestyle of each grouping. However, one of their important characteristics is that all groups create - in the real space of the city, the digital space of the internet, or both - places that play a fundamental role in creating and displaying their identity: these places serve as starting points 
for cultural practices that help organize everyday life, create opportunities for the establishment of the social net, and even provide a platform on which to formulate and visualize ideas about themselves and their own ethnicity.

These sites (venues of cultural events, religious scenes, shops, concert halls, cafés, forums, Facebook groups - and the list could go on) - according to the previously mentioned study by Norwegian ethnographers Elisabet M. Nilsson and Veronica Wiman (Nilsson - Wiman 2015) - can be considered performative memorial spaces where the cultural background, special experience, and knowledge set of the members of these groups can be seen. This is the knowledge - the performative memory of the group as important elements of the cultural heritage of the city - that are collected, stored, and shared together with members of these groups during the archiving process. ${ }^{13}$

\section{THE BERLIN SITE}

Connecting the data generated on city networks and in city planning is also a current problem in Berlin. In the fall of 2016, the city made data about the operation of infrastructure available to the wider public. Although the expert responsible for the City Hall Project primarily emphasized the importance of cultural data (the geo-data of cultural institutions, cultural budget and aid rates, data about visitor research), the principle he expressed applies to other areas of the city's operations (e.g. population movement): "We want to make the data accessible and reusable. Citizens have paid the cost of creating them and they should be allowed access" (Pressemitteilung 2016).

In order to incorporate this wide range of data and initiatives of data collection and utilization into a single framework, the Senate Department for Urban Planning, the districts, and the Berlin-Brandenburg Statistical Office jointly established a map called Lifeworld Spaces (Lebensweltlich orientierten Räume - LOR). The main purpose was to map lifeworld homogeneity; i.e. so that the

13 Social science literature that deals with collaboration and social participation is quite diverse. An important branch of this is collaborative anthropology, characterized by the name of Luke Eric Lassiter, which thematizes the participation of the studied community at the different levels of knowledge production and knowledge use processes (Lassiter 2005a, 2005b). The present study considers collaborative process as a way of thinking and practice, in which theory and empirical research appear as tools for dealing with everyday situations and for overcoming problems. Through collaboration, the research results created by the researcher and the studied community can be used to solve the problems of everyday life and to design future frameworks. (There are a number of issues and problems to be considered in the collaborative process; for the epistemological, ethical, and practical problems, see Binder 2013). 
planning of traffic does not dominate and create the space hierarchy, but rather the basic structure is defined along the lines of uniform architectural structures, milieus, population numbers, and natural boundaries. The decision by the Berlin Senate, dated August 1, 2006, stated that these new spatial principles should be taken into account for all types of demographic and social planning, forecasting and observation, and similarly, the statistical office's data recordings have to be included in this map as well.

As a result, an interactive, so-called OpenStreetMap ${ }^{14}$ was created based on urban open data. The source of the map is the various statistical data collected by the Berlin-Brandenburg Statistical Office, such as the demographic surveys of 2007-2015. These statistics are published in the OpenDataBerlin project (https:// daten.berlin.de/). The base map created with the LOR principles in mind divides Berlin into 447 residential areas ("neighborhoods") that can be sorted into different clusters (groups with distinctive markings). The following variables are taken into account during the grouping: gender, age, migration background, quality of housing, and duration of residence. In this way, it is possible to examine the ethnic composition of the various districts and neighborhoods of the city through an interactive data-visualization process. Hovering the mouse cursor over individual residential areas displays the most important principles of cluster classification, the ethnic composition of the given area, the number of houses, etc.

Several significant improvements and applications have been created in connection with this map, two of which are worth highlighting here. The application called Interactive Berlin: Clustering Neighborhoods is trying to answer some very simple questions that are often asked in everyday life: namely, what is the reason that some districts are found to be attractive, while others alarming, and why are some districts similar - or different - to others (http://www.100-percent.net/projects/berlin\#about). Using statistical data, the application determines clusters and district-types using five variables. The application Interactive Berlin: Where Do You Live? is also based on a very simple principle based on everyday life experience: "Tell me who you are, and I'll tell you where you live!" The application helps predict where a conversation partner or interviewee is likely to live in one of Berlin's 447 neighborhoods, based on only a minimum of personal information collected during a conversation. The prediction utilizes data available on public surfaces by perusing anonymized tables (http://www.100-percent.net/projects/berlin_residence\#about).

14 Established in 2004, the OpenStreetMap project was designed to create a free world map that can be used to collect various data (including streets, houses, rivers, forests, and anything else that can be depicted on the map). 
This cultural mapping technology can be used in the research of urban ethnic groups (Insole - Piccini 2013). Thus, it can provide an adequate framework for presenting the history, relations, and heritage of Hungarian groups living in Berlin. ${ }^{15}$ Since data sets related to the immigration to Berlin and the location of Hungarian ethnic groups in the city are available going back to the 1990s, the spatial location as well as the changes to the location of groups identified by the statistical office as "Hungarian" can be clearly visualized along a timeline, and the history and present of the "Hungarian migration" can be drawn on the map of greater Berlin. In addition, it can be demonstrated and contextualized how the spatial movement of these groups fits into larger, typical mobility processes. To what extent can the urban-spatial mobility of groups identified as "Hungarian" be considered unique, or possessing general characteristics?

Different layers can be added to the base map, which the user can freely turn on and off. Layers in fact are area layouts that focus on and display different contents or chronological sections. On the one hand, they aim to "zoom in on" the urban-spatial processes presented by the base map to showcase and interpret their various aspects. On the other hand, these layers can be used to identify what specific features can be discovered in the presence of groups identified as "Hungarian" in Berlin and how the latter create different locations, develop social networks, and formulate specific city readings. Layers offer users the opportunity to interact and encourage them to participate and collaborate: the selection of new places can be initiated on the given user interfaces, relevant information can be linked to them, and opinions, critiques, and additions can be attached to the uploaded data. ${ }^{16}$

\section{SUMMARY}

The focus of this paper was a pilot project plan that attempts to redefine one of the classical areas of the social sciences - the research of metropolitan ethnic communities - in the new situation resulting from the socio-political-

15 The fundamental aim of this study is to reinforce the need to create such a cultural mapping process and clarify its most important principles and theoretical and methodological contexts. The concrete implementation depends on the grant and infrastructure opportunities.

16 Regarding the Bristol project, the necessary basic processes for building a similar map were described as: "In order to achieve the kind of analysis necessary in the planning process requires a longer-term project that combines ethnography with the technical expertise and resources to digitize and archive home movies and to provide communities and individuals with both online and personal access to these archives" (Insoles - Piccini 2013, 41). 
media-cultural changes of recent decades. It discusses two major problems in detail: how to respond to the new situation arising from digitalization, and the participatory revolution.

The study, with strong emphasis on using the most important principles and methodology of cultural mapping, presents the criteria for implementing a pilot project according to the following principles.

The project looks at the common points of the everyday life of ethnic group(s) and city history, paying particular attention to the dimension of media usage.

The project is present in both the offline and online world, and at the same time it also draws attention to the interaction between them. The research activity takes place simultaneously in two related areas: both the social spaces used by the groups and the online interfaces created by them represent fundamental reference points. The thematization of the relationship between real-world, urban-spatial social structures and the digital content of online surfaces plays an important role both in the research activity and the presentation of the results.

The project is based on collaborative principles. The collection, organization and interpretation of data is the competence of not only the research personnel, but also a possibility offered to the members of the investigated groups. That is to say, the project builds on participation to create collaborations with different (offline and online) groups, their members and representatives at all stages of the research.

The past and the future are both present in the direction vector of the research (application). While exploring, archiving, and publicizing the cultural heritage of the past play an important role in the project, the knowledge and skills thus created are important for potentially shaping the future. How the knowledge generated by ethnic group(s) can be incorporated into the current processes of urban planning and how these can shape the urban plans of the future and contribute to urbanistic thinking are some of the most important issues here.

The research does not create closed data (stored in archives), but builds a public interface that relies on open data accessible to everyone. While finding, gathering, prototyping, and arranging (oral, visual, and material) resources may evoke the classic methods of the archiving process, the project aims to create a digital platform by using open data. It is an important goal that any open archive created on this platform can be freely used, supplemented, and shared by anyone.

The end result of the project is not a closed unit, but a model-like, expandable knowledge structure that may be supplemented. Our knowledge of this particular section of metropolitan mobility can be further developed for the given group; that is to say, the digital platform can be linked with newer layers that show interactions between the ethnic group and the urban space from other 
perspectives. On the other hand, model building can extend to neighboring areas, showing how the same process is being conducted for other ethnic groups.

\section{REFERENCES}

Binder, Beate - Friedrich von Bose - Katrin Ebell - Sabine Hess - Anika Keinz eds., (2013), Eingreifen, Kritisieren, Verändern!? Interventionen ethnographisch und gendertheoretisch, Münster, Westfälisches Dampfboot

Bojadžijev, Manuela - Regina Römhild (2014), "Was kommt nach dem »transnational turn«? Perspektiven für eine kritische Migrationsforschung," in: Labor Migration ed., Vom Rand ins Zentrum. Perspektiven einer kritischen Migrationsforschung, Berlin, Panama Verlag, 2014, pp. 10-25.

Çağlar, Ayşe (2002), "Media Corporatism and Cosmopolitanism", in: Vertovec, Steven - Robin Cohen, eds., Conceiving Cosmopolitism. Theory, Context, and Practice, Oxford, New York, Oxford University Press, pp. 180-190.

Cosgrove, Denis (2008), "Cultural cartography: Maps and mapping in cultural geography", Annales de Géographie, No 2-3, pp. 159-178. (Downloaded: 16.10.2017) http://www.cairn.info/article.php?ID_ ARTICLE=AG_660_0159\#re21no81; http:/dx.doi.org/10.3917/ag.660.0159

Császár, Balázs (2013), "A részvétel fogalom társadalomelméleti összefüggései" (The social theoretical context of the concept of participation), Belvedere Meridionale, Vol. 25, No 3, pp. 15-30. http://dx.doi.org/10.14232/ belv.2013.3.2

De Haas, Hein (2010), "The Internal Dynamics of Migration Processes: A Theoretical Inquery", Journal of Ethnic and Migration Studies, Vol. 36, No 10, pp. 1587-1617. http:/dx.doi.org/10.1080/1369183X.2010.489361

Derrida, Jacques - Ernst Wolfgang (2008), Az archívum kinzó vágya / Archívumok morajlása, (Stirrings in the Archives: Order from Disorder.) Budapest, Kijárat Kiadó Ders, Csaba (2016), "Egy okos Pécs felé”, Információs Társadalom, Vol. 16, No 3, pp. 23-82. http://dx.doi.org/10.22503/inftars.XVI.2016.3.2 Diminescu, Dana (2008), "The connected migrant: an epistemological manifesto", Social Science bInformation, Vol. 47, No 4, pp. 565-579. http:/ dx.doi.org/10.1177/0539018408096447

Duxbury, Nancy - W. F. Garrett-Petts - David MacLennan (2015), "Cultural Mapping as Cultural Inquiry. Introduction to an Emerging Field of Practice", in: Duxbury, Nancy - W.F. Garrett-Petts - David MacLennan eds., Cultural mapping as cultural inquiry, New York, London, Routledge, Taylor \& Francis, pp. 1-45. Editorial (2014), "Stadt und Migration - Neue Forschungsansätze 
zu citizenship, Macht und agency”, sub/urban. Zeitschrift für kritische Stadtforschung, Vol. 2-3; pp. 5-13.

Faist, Thomas (2016), "Cross-Border Migration and Social Inequalities", Annual Review of Sociology, Vol. 42, No 1, pp. 323-346. https://doi.org/10.1146/ annurev-soc-081715-074302

Fejérdi Tamás - Z. Karvalics László (2015), “Kis- és közepes városok kulturális rezilienciasúlypontjai" (Cultural Resilience-Centers of Small and Medium Cities), Replika, Vol. 94, pp. 113-127.

Flade, Antje ed. (2015), Stadt und Gesellschaft im Fokus aktueller Stadtforschung Konzepte. Herausforderungen, Perspektiven, Wiesbaden, Springer Fachmedien

Florida, Richard (2005), Cities and the creative class. New York u.a., Routledge. Glick Schiller, Nina - Linda Basch - Cristina Blanc Szanton (1992), "Transnationalismus. Ein neuer analytischer Rahmen zum Verständnis von Migration", in: Kleger, Heinz ed., Transnationale Staatsbürgerschaft, Frankfurt a. M., Campus Verlag, pp. 81-108.

Glick Schiller, Nina - Ayşe Çağlar - Thaddeus C. Guldbrandsen (2006), "Jenseits der „ethnischen Gruppe“ als Objekt des Wissens”, in: Berking, Helmuth ed., Die Macht des Lokalen in einer Welt ohne Grenzen, Frankfurt a. M., Campus Verlag, pp. 105-144.

Glick Schiller, Nina - Salazar, Noel B. (2013), "Regimes of Mobility Across the Globe", Journal of Ethnic and Migration Studies Vol. 39, No 2, pp. 183-200. https://doi.org/10.1080/1369183X.2013.723253

Harrison, C., - Donnelly, I. (2011), A theory of smart cities, Proceedings of the 55th Annual Meeting of the ISSS - 2011, Hull, UK, Vol. 6 (Downloaded: 16.10.2017) view/1703.

Hepp, Andreas - Caroline Düvel (2010), "Die kommunikative Vernetzung in der Diaspora: Integrations- und Segregationspotenziale der Aneignung digitaler Medien in ethnischen Migrationsgemeinschaften", in: Jutta Röser - Tanja Thomas - Corinna Peil eds., Alltag in den Medien - Medien im Alltag, Opladen, Westdeutscher Verlag, pp. 261-281. Host, Heather - Miller, Daniel eds., (2012) Digital Anthropology, Oxford, Berg Publishers

Insole, Peter - Angela Piccini (2013), "Your Place or Mine? Crowdsourced Planning, Moving Image Archives and Community Archaeology", Archäologische Informationen Vol. 36, pp. 31-43. http:/dx.doi.org/10.3390/ heritage 2010001

Jenkins, Henry (2006), Convergence Culture. Where Old and New Media Collide, New York, London, New York University Press. 
Kitchin, Rob - Perkins, Chris - Dodge, Martin (2009), "Thinking about maps", in: Dodge, Martin - Rob Kitchin - Chris Perkins eds., Rethinking maps: New frontiers in cartographic theory, London, Routledge, pp. 1-25.

Open Data Handbook (2012), Http://www.w3c.hu /forditasok/Open-DataHandbook/OpenDataHandbook_en.pdf. Krätke, Stefan (2001), "Berlin: Towards a Global City?" Urban Studies, Vol. 38, No 10, pp. 1777-1799. http:/ dx.doi.org/10.1080/00420980120084859 Neirotti, Paolo - De Marco, Alberto - Cagliano, Anna Corinna (2014), "Current trends in smart city initiatives: Some stylized facts", Cities, Vol. 38, pp. 25-36. http:/dx.doi.org/10.1016/j. cities.2013.12.010

Lassiter, Luke Eric (2005a), The Chicago Guide to Collaborative Ethnography, Chicago, London, The University of Chicago Press

Lassiter, Luke Eric (2005b), "Collaborative Ethnography and Public Anthropology", Current Anthropology, Vol. 46, No 1, pp. 83-106. http:/ dx.doi.org/10.1086/425658

Manoff, Einat (2014), Destabilizing the map through critical cartography and resistance; https://peopleplacespace.org/frr/destabilizing-the-map-throughcritical-cartography-and-resistance/ (Downloaded: 20.02.2019)

Miller, Daniel et al. (2016), How the World Changed Social Media, London, UCL Press

Nilsson, Elisabet M. - Veronica Wiman (2015), Urban Archiving for Smarter Cities Archival practices beyond Open data, Conference proceedings, Culture and Computing Kyoto University, Japan

Open-Data-Handbook (2012) http://www.w3c.hu/forditasok/Open-DataHandbook/OpenDataHandbook_hu.pdf (Downloaded: 20.02.2019)

Pressemitteilung (2016) Senatskanzlei Berlin, Kulturelle Angelegenheiten. https://daten.berlin.de/interaktion/artikel/open-data-\%E2\%80\%93berliner-kulturverwaltung-\%C3\%B6ffnet-ihre-daten (Downloaded: 20.02.2019).

Pries, Ludger (2010), Transnationalisierung. Theorie und Empirie grenzüberschreitender Vergesellschaftung, VS Verlag für Sozialwissenschaften, Springer Fachmedien Wiesbaden GmbH. Replika, Reziliencia és társadalom (Resilience and Society), Vol. 94, pp. 7-127.

Roberts, Les - Sara Cohen (2015), "Mapping Cultures. Spatial Anthropology and Popular Cultural Memory", in: Duxbury, Nancy - W.F. Garrett-Petts David MacLennan eds., Cultural mapping as cultural inquiry, New York, London, Routledge, Taylor \& Francis, pp. 170-198.

Salamin, Géza ed., (2015), Cities in action reflecting global economic challenges and technological trends with special reference to the smart city concept, Budapest, Magyar Urbanisztikai Társaság 
Stewart, Sue (2007), Cultural mapping toolkit, Vancouver, Creative City

Network of Canada and 2010 Legacies Now Stewart, Sue (2014), "The Creative City Network of Canada", Cultural Mapping Toolkit, No 8. sub/ urban (2014), Zeitschrift für kritische Stadtforschung, Vol. 2-3, pp. 81-93. sub/urban. Zeitschrift für kritische Stadtforschung, Stadt und Migration Neue Forschungsansätze zu citizenship, Macht und agency, 2014/3.

Szijártó, Zsolt (2010), "Koncepció és kontextus. Az EKF-projekt és Pécs" (Concept and context. The EKF project and Pécs), in: Elemzö értékelés aPécs 2010 Európa Kulturális Fövárosa program tapasztalatairól. (Evaluation of the experiences of the Pécs 2010 European Capital of Culture program) Pécs, pp. $155-166$.

Taylor, Ian - Karen Evans - Penny Frasen (1996), Tale of Two Cities: Global Change, Local Feeling, and Everyday Life in the North Of England: A Study in Manchester and Sheffield, London, New York, Routledge Terkessidis, Mark (2015), Kollaboration, Frankfurt, Suhrkamp. Vertovec, Steven (2007), "Super-diversity and its Implications", Ethnic and Racial Studies Vol. 29, No 6, pp. 1024-1054. http://dx.doi.org/10.1080/01419870701599465 